\title{
Stimulating Trade and Development of Indigenous Cultural Heritage by Means of International Law: Issues of Legitimacy and Method
}

\author{
Christoph B. Graber*
}

JANUARY 2012

\begin{abstract}
Adopting the view that a more active participation of indigenous peoples in the trade of their knowledge assets would promote their socioeconomic development raises difficult questions of legitimacy and method. Questions of legitimacy are posed by the potentially modernising effects of development endangering traditional ways of indigenous peoples' social organisation. Questions of method arise when studying how international law, including international economic law, could better contribute to furthering the development interests of indigenous peoples in the trade of indigenous cultural heritage (ICH). There will be many areas where modern law and indigenous custom collide. These questions are the focus of the first part of the paper. The second part studies international law's potential to stimulate ICH trade for the sake of indigenous socioeconomic development. To this end, it first assesses how interests of indigenous peoples in trade and development of $\mathrm{ICH}$ are currently institutionalised in international economic law. The paper then examines whether preferential trade rules for indigenous cultural goods and services would be an adequate tool to advance the interests of indigenous peoples in ICH trade and development.
\end{abstract}

\section{KEY WORDS}

Indigenous knowledge, trade and development, international law, preferential trade rules, methodology.

\footnotetext{
* Christoph Beat Graber is Professor of Law and Head of the IT ICH (International Trade of Indigenous Cultural Heritage) project and the i-call (International Communications and Art Law Lucerne) research centre, at the University of Lucerne. Contact at christoph-beat.graber@unilu.ch. The author would like to thank Christoph Antons, Peter Drahos, Karolina Kuprecht, Jessica Lai, Federico Lenzerini, Axel Tschentscher and Peter Yu for helpful comments. The support from the Swiss National Science Foundation and the Ecoscientia Foundation is gratefully appreciated.
}

I-CALL WORKING PAPERS are the result of research that takes place through the i-call research centre. The papers have been peer-reviewed.

Suggested CitATION: Graber, Christoph B., 'Stimulating Trade and Development of Indigenous Cultural Heritage by Means of International Law: Issues of Legitimacy and Method', University of Lucerne, Switzerland, i-call Working Paper No. 01 (2012), forthcoming in Christoph B. Graber, Karolina Kuprecht and Jessica C. Lai (eds), International Trade in Indigenous Cultural Heritage: Legal and Policy Issues, Cheltenham, UK: Edward Elgar, 2012. 
Published by:

i-call, The Research Centre for International Communications and Art Law at the University of Lucerne

Frohburgstrasse 3

P.O. Box 4466

6002 Lucerne

Switzerland

ISSN 1664-0144

(C) The i-call Research Centre, Switzerland

All rights reserved. No part of this publication may be reproduced, stored in a retrieval system, or transmitted in any form or by any means, mechanical, photocopying, recording or otherwise, without prior written permission of the publisher.

Permission to use this content must be obtained from the copyright owner. 
STIMULATING TRADE AND DEVELOPMENT OF INDIGENOUS CULTURAL HERITAGE BY MEANS OF INTERNATIONAL LAW: ISSUES OF LEGITIMACY AND METHOD

1. INTRODUCTION.................................................................................. 4

2. DEVELOPMENT AS FREEDOM FOR INDIGENOUS PEOPLES ... 6

3. INTERFACING INDIGENOUS AND MODERN WORLDVIEWS: A PROCEDURAL APPROACH............................................................ 10

3.1 PROCEDURALIST THINKING IN SOCIAL THEORY ……......................... 10

3.2 A PROCEDURAL APPROACH TO TRADE IN ICH ................................... 12

3.3 INTERIM CONCLUSIONS .............................................................. 16

4. INDIGENOUS CULTURE AND DEVELOPMENT IN

INTERNATIONAL ECONOMIC LAW .......................................... 17

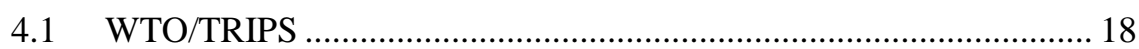

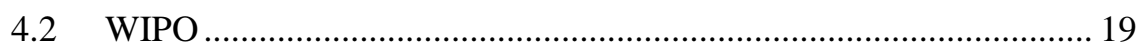

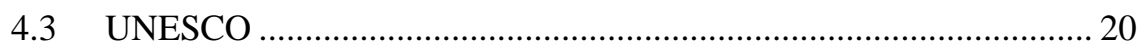

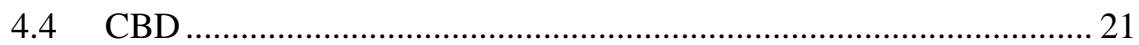

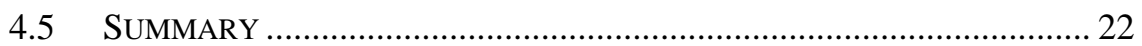

5. PROS AND CONS OF PREFERENTIAL TRADE RULES FOR INDIGENOUS PEOPLES STIMULATING A MORE ACTIVE ROLE OF INDIGENOUS PEOPLES IN GLOBAL TRADE........... 23

6. CONCLUSION ............................................................................................. 27 


\section{INTRODUCTION}

Under the effects of economic globalisation and the internet, international trade in traditional knowledge (TK) and traditional cultural expressions (TCE) is gaining magnitude and a debate about the law's role in protecting indigenous cultural heritage $(\mathrm{ICH})^{1}$ seems more necessary than ever. So far, the dominant attitude in this debate has been a defensive one. Scholars backed by prominent indigenous brokers have been arguing for some decades that the international legal order should work out efficient defences against flagrant misappropriation of ICH. The international restitution of stolen or illegally exported indigenous cultural property indeed leaves a lot to be desired and the existing intellectual property (IP) regime does not provide effective remedies against misappropriation of TK and TCE. ${ }^{2}$ Although these concerns need to be addressed, ${ }^{3}$ I think that the debate should not stop there. Instead, I suggest a shift from a defensive attitude to a proactive strategy and to study whether international trade in ICH could promote social and economic development of indigenous peoples and how the law could contribute to this aim.

The concept of "development" is understood here in line with Amartya Sen's seminal book "Development as Freedom" and "[a]ttention is thus paid particularly to the expansion of the 'capabilities' of persons to lead the kind of lives they value and have reason to value." 4 Sen has made it clear that this philosophical concept should not be limited to the poor people in developing countries since "the richer countries too often have deeply disadvantaged people, who lack basic opportunities". ${ }^{5}$ This is certainly also true for indigenous peoples who often belong to the most disadvantaged segments of society. Accordingly, there is good reason to assume in this chapter, that the concept "development as freedom" can also be extended mutatis mutandis to the indigenous peoples in rich countries, including the USA, Canada, Australia or New Zealand.

Adopting the view that a more active participation of indigenous peoples in the trade of their knowledge assets would promote their social and economic development raises difficult questions of legitimacy and method.

Questions of legitimacy will be posed by the potentially modernising effects of development endangering traditional ways of indigenous peoples' social

1 Whereas TK, TCE (sometimes also called "Folklore"), biological and genetic resources or indigenous cultural and intellectual property (ICIP) are among the many terms that are used to describe the subject matter, indigenous peoples often prefer to speak of indigenous cultural heritage (ICH). Whereas most of the above mentioned terms reflect the ways in which modern law categorises indigenous knowledge assets and thus subjects indigenous culture under a modern episteme, indigenous cultural heritage respects indigenous peoples' epistemological sovereignty. Accordingly, the latter term is used in this chapter.

2 This is because the IP system leaves many modes of TK and TCE outside the scope of protection.

3 See in particular Rebecca Tsosie, 'International Trade in Indigenous Cultural Heritage: An Argument for Indigenous Governance of Cultural Property', in this volume; Rosemary J. Coombe and Joseph F. Turcotte, 'Indigenous Cultural Heritage in Development and Trade: Perspectives from the Dynamics of Cultural Heritage Law and Policy', in this volume; Christoph Antons, 'Intellectual Property Rights in Indigenous Cultural Heritage: Basic Concepts and Continuing Controversies', in this volume; Brigitte Vézina, 'Are They In or Are They Out? Traditional Cultural Expressions and the Public Domain: Implications for Trade', in this volume; and Martin Girsberger and Benny Müller, 'International Trade in Indigenous Cultural Heritage: An IP Practioners' Perspective', in this volume.

$4 \quad$ Amartya K. Sen, Development as Freedom, 1st edn, New York: Anchor Books, 2000, at p. 18.

$5 \quad$ Ibid., at p. 15. "Even within very rich countries, sometimes the longevity of substantial groups is no higher than that in much poorer economies of the so-called third world." 
organisation. For Sen, it is "the people directly involved who must have the opportunity in deciding what should be chosen" if a traditional way of life must be given up because of modernising effects entailed by development. ${ }^{6}$ This chapter will further elaborate on some difficult problems that must be resolved when such an approach is followed in a legal context including conflicts between rights of the group with rights of individual members of the group.

Questions of method arise when studying how international law, including international economic law, could better contribute to furthering development interests of indigenous peoples in the trade of $\mathrm{ICH} .^{7}$ There will be many areas where modern ${ }^{8}$ law and indigenous custom collide. As the indigenous sociologist Duane Champagne argued, any effort to draft better legal solutions will be challenged by unbridgeable differences between indigenous and non-indigenous worldviews. ${ }^{9}$

From an epistemological perspective, the difference between indigenous and non-indigenous worldviews implies that in our scientific aspirations of gaining knowledge we are ultimately always stopped at a point where a veil covers what cannot be accessed by a modern mind. What are the consequences of this insight for our research? A first consequence is simply to be conscious that this difference exists and that it cannot be negotiated. From this follows the second consequence. If access to the core of the indigenous world is not possible for a non-indigenous mind, then the question is how we, as (modern) lawyers and social scientists, should methodologically deal with the impossibility of looking behind the veil.

The response that this research project has given to the problem is twofold. Following an approach of transdisciplinary research, we have first been very careful to include indigenous scholars and stakeholders into all steps of the research process. According to one definition, a key element of transdisciplinarity consists in participatory research, i.e. the inclusion of the most relevant stakeholders into the research process. ${ }^{10}$ In line with this exigency of transdisciplinarity, the active participation of indigenous scholars and stakeholders shall prevent the research project from falling into the traps of scientific colonialism or paternalism. However, a word of caution is necessary to avoid exaggerated expectations. As for any one group of researchers or projects we must acknowledge that such an approach sets practical difficulties on what can be accomplished. In particular, one must bear in mind that indigenous persons designated as "experts" for indigenous worldviews by nonindigenous systems of recognition enter a dual world which potentially distances them from indigenous peoples living traditional lives. ${ }^{11}$ Second, we suggest relying on procedural approaches rather than on substantive solutions when dealing with indigenous issues in law and policymaking. The basic features of such a procedural approach shall be explored in this chapter.

After considering the problems related to legitimacy and method, the chapter will turn to issues related to the international law's potential in stimulating ICH

\footnotetext{
Ibid., at p. 31.

The concepts "traditional" as opposed to "modern" culture are used in this chapter in a strictly sociological sense and do not entail any value judgements.

8 Terms like "modern" (as opposed to "traditional" or "indigenous') or "modernisation" are used throughout this chapter in a sociological sense to distinguish patterns of social organisation and do not entail any value judgments. Hence, I am by no means saying that a "modern" social structure should anyhow be preferred over a traditional or indigenous one.

9 See Duane Champagne, 'Indigenous Self-Government, Cultural Heritage and International Trade: A Sociological Perspective', in this volume.

10 Christian Pohl and Gertrude Hirsch Hadorn, Principles for Designing Transdisciplinary Research, Munich: oekom, 2007, at pp. 70-72.

11 I would like to thank Peter Drahos for pointing this out.
} 
trade for the sake of indigenous social and economic development. To this end it first assesses how interests of indigenous peoples in trade and development of ICH are currently institutionalised in international economic law. ${ }^{12}$ Second, the chapter examines whether preferential trade rules for indigenous cultural goods and services would be an adequate tool to advance the interests of indigenous peoples in ICH trade and development.

\section{DEVELOPMENT AS FREEDOM FOR INDIGENOUS PEOPLES}

Indigenous peoples appear generally at the lower end of socioeconomic statistics and even in first world countries they belong to the most disadvantaged groups in many respects, including life expectancy, income, education etc. ${ }^{13}$ From this perspective, a policy contributing to improving their social and economic development seems to be persuasive. However, critics have objected that development may have harmful effects and even destroy traditions and cultural heritage of indigenous peoples. ${ }^{14}$ Based on Amartya Sen's concept of "development as freedom", it is possible to respond to this objection in two tiers. First, it must be recalled that for Sen, development is viewed as an "expansion of freedom" ${ }^{15}$ and attention is thus given more to the end of development than to its means. Accordingly, the contributions of development to the growth of personal capabilities are more important than its contributions to economic growth. Similarly, the primary significance of the market is seen in its participatory dimension as an institution enabling freedom of interchange. ${ }^{16}$ If the freedom aspect of the market is emphasised, the focus should not be on utilities, incomes or wealth (the "culmination outcomes" of the market) but rather on "the process of getting there, including the exercise of freedom". ${ }^{17}$ The second element of the objection relates to the potentially modernising effect of development involving the destruction of traditions and cultural heritage. Sen concedes that it would not be sufficient to dismiss this objection with the argument "that it is better to be rich and happy than to be impoverished and traditional". ${ }^{18}$ Such an argument would fall short of considering that the authority and legitimacy of such a decision is problematic. As stated by Sen: "There is an inescapable valuational problem involved in deciding what to choose in and when it turns out that some parts of tradition cannot be maintained along with economic or social changes that may be needed for other reasons." 19

12 The term "international economic law" is understood broadly to encompass also trade-related legal aspects of intellectual property, cultural property and tangible and intangible cultural heritage.

13 For the situation in the US see the comprehensive, systematic and comparative study of social, economic and political conditions of American Indian reservations, undertaken by the Harvard Project on American Indian Economic Development over the last 20 years: Eric C. Henson et al. (eds), The State of the Native Nations. Conditions under U.S. Policies of Self-determination, New York: Oxford University Press, 2008.

14 For a generally defensive posture towards participation of indigenous peoples in international trade, see, e.g. Champagne, supra note 9, and the discussion in Fiona Macmillan, 'Finding Space in the Margins? Recognising the Rights of Indigenous Peoples in the WTO', in this volume. See also Robert K. Paterson and Dennis S. Karjala, 'Looking Beyond Intellectual Property in Resolving Protection of the Intangible Cultural Heritage of Indigenous Peoples' (2003) Cardozo Journal of International and Comparative Law, 11, pp. 633-670, at p. 634 .

15 Sen, supra note 4 , at p. 36 .

$16 \quad$ Ibid., at p. 6.

$17 \quad$ Ibid., at p. 27.

18 Ibid., at p. 31.

19 Ibid. 
The answer Sen offers to resolve the identified problem is participation. Choosing about its destiny is a decision that only a people directly involved can legitimately take. If it is up to the people involved to choose, it is necessary that it receives "the opportunity to participate in deciding what should be chosen". ${ }^{20}$ From a legal perspective, one may easily agree to such a precept since allowing an (indigenous) people to decide freely on what traditions to follow is part of its collective right of self-determination and self-government as recognised by the UN Declaration on the Rights of Indigenous Peoples (UNDRIP). ${ }^{21}$ Although the UNDRIP is not a binding instrument of public international law, ${ }^{22}$ it is relevant as a political tool and will most likely influence future law and policymaking on indigenous issues at all levels. ${ }^{23}$

For Sen, the real philosophical quandary is the question whether participation should also be a precept within a traditional people or group. ${ }^{24}$ Ultimately, the problem is the relationship between the rights of the group and the rights of individual members of the group. This is a frequent conflict situation in indigenous contexts. ${ }^{25}$ Here the question arises whether and, if yes, to what extent an indigenous group can internally enforce its traditional custom against dissenting individual members of the group. What should be the normative reference for deciding this question? Should it be indigenous custom or should it be modern law? Sen does not discuss this question in detail. However, the examples he provides as an illustration of his general argument clearly show that he would opt for the participatory freedom of the individual within the group and, in a case of conflict, against the customary rules of the traditional group or people. Sen argues: ${ }^{26}$

An attempt to choke off [internal] participatory freedom on grounds of traditional values (such as religious fundamentalism, or political custom, or the so-called Asian values) simply misses the issue of legitimacy and the need for the people to participate in deciding what they want and what they have reason to accept.

20 Ibid.

21 UN, Declaration on the Rights of Indigenous Peoples (UNDRIP), GA Res. 61/295 (UN Doc. A/61/L.67 and Add.1) (adopted on 13 September 2007), Articles 3 and 5, protecting the right of (collective) selfdetermination and the right of collective self-government, respectively.

22 On the controversy regarding the reach and impact of the right of self-determination in international law, see Daniel Thürer and Thomas Burri, 'Self-Determination', in Rüdiger Wolfrum (ed.), The Max Planck Encyclopedia of Public International Law, Oxford: Oxford University Press, 2008, available online at http://www.mpepil.com/subscriber_article?script=yes\&id=/-epil/entries/law-9780199231690-

e873\&recno=2\&searchType=Quick\&query=Thomas+Burri (all online sources were accessed 7 September 2011). See also Christoph B. Graber, 'Aboriginal Self-Determination vs the Propertisation of Traditional Culture: The Case of Sacred Wanjina Sites' (2009) Australian Indigenous Law Review, 13 (2), pp. 18-34, at p. 26 [hereinafter Graber, 'Aboriginal Self-Determination']; and Jessica C. Lai, 'The Protection of Māori Cultural Heritage Post-Endorsement of the UN Declaration on the Rights of Indigenous Peoples', University of Lucerne, Switzerland, i-call Working Paper No. 2 (2011), at pp. 8-34, available online at http://www.unilu.ch/files/i-call_Working_Paper_2011_02_Lai_Maori_Cultural_Heritage_UNDRIP.pdf [hereinafter Lai, 'Māori Cultural Heritage and UNDRIP'].

23 The Declaration was adopted by the UN General Assembly on 13 September 2007. One hundred and fortythree UN Member States voted in favour, 11 abstained and four - Australia, Canada, New Zealand and the United States - voted against the instrument. Since its adoption, Australia, New Zealand, Canada and the United States have all reversed their positions and now endorse the Declaration. Colombia and Samoa have also indicated their support for the Declaration. For an account of the relevance of the UNDRIP as a political tool see Lai, 'Māori Cultural Heritage and UNDRIP', supra note 22, at pp. 26-30.

24 Sen, supra note 4 , at p. 32.

25 For examples of US Law see Carole Goldberg, 'A United States Perspective on Protection of Indigenous Cultural Heritage', in this volume.

26 Sen, supra note 4 , at p. 32. 
The consequence of a normative requirement for internal participation would be that individual members of the group could not legitimately be required to obey to traditional custom based decisions of the group. This is only consequent if considering Sen's general emphasis on the pre-eminence of democratic structures. ${ }^{27}$ However, from a legal perspective it would be necessary to introduce a distinction between indigenous and non-indigenous groups. ${ }^{28}$ This is indispensable because the collective right of self-determination and self-government of indigenous peoples is specifically protected under the UNDRIP. ${ }^{29}$ Affirming an unlimited and unspecified right of internal participation would thus ignore collective rights of indigenous peoples. On the other hand, an absolute rejection of modernity would risk violating human rights of individual members of the indigenous group or people. In certain cases of cultural or ritual practices of indigenous peoples (including honour killing, female circumcision or spearing and other physical punishment $)^{30}$ the primacy of indigenous customary law would indeed create conflicts with core human rights standards (ius cogens) and international ordre public. Fortunately, the UNDRIP itself provides for a solution to such collisions between indigenous custom and modern law. According to Article 34 UNDRIP, indigenous peoples must respect international human rights standards when making use of the "right to promote, develop and maintain their institutional structures and their distinctive customs, spirituality, traditions, procedures, practices".

According to Sen, native cultures cannot escape from effects of the globalising world, even if they are harmful. ${ }^{31}$ Because the forces of global exchange and trade are difficult to resist in a world dominated by modern information and communication technologies the option to stop globalisation is arguably not available for local cultures. $^{32}$ In my view, however, it would be oversimplifying to see participation in a capitalist economy or the use of modern communication technologies as solely a threat to local identities. The internet, in particular, may help indigenous communities to overcome isolation. It has indeed become extremely valuable for people living in remote areas for purposes like schooling or telemedicine. ${ }^{33}$ Moreover, the internet may provide a useful tool to communicate with like-minded groups around the world and to build coalitions, particularly in international and regional policymaking. It may also offer new opportunities to communities which want to take advantage of economic globalisation, enter trade relations and gradually move

$27 \quad$ Ibid., at pp. 146-159.

28 Sen addresses conflicts between traditional and modern worldviews in general without discussing indigenous issues in particular.

29 For the legal protection of the collective rights of self-determination and self-government of indigenous peoples under the UNDRIP see supra note 22, and accompanying text. For a philosophical defence of the argument that indigenous communities must be able to live according to their cultural practice see Chandran Kukathas, 'Are There Any Cultural Rights?', in Will Kymlicka (ed.), Multicultural Citizenship: A Liberal Theory of Minority Rights, Oxford: Clarendon Press, 1996, pp. 228-256. Kukathas conceives the right of the individual to leave the community to be crucial. For a discussion of this argument from a human rights perspective see Christoph B. Graber, 'Using Human Rights to Tackle Fragmentation in the Field of Traditional Cultural Expressions: An Institutional Approach', in Christoph B. Graber and Mira BurriNenova (eds), Intellectual Property and Traditional Cultural Expressions in a Digital Environment, Cheltenham, UK: Edward Elgar, 2008, pp. 96-120, at pp. 114-118.

30 On spearing as an Aboriginal form of punishment, see Heather McRae et al., Indigenous Legal Issues, Commentary and Materials, 3rd edn, Sydney: Thomson, 2003, at pp. 549-551.

31 Sen, supra note 4 , at p. 32 .

32 Ibid., at p. 240.

33 See Kyra Landzelius (ed.), Native on the Net: Indigenous and Diasporic Peoples in the Virtual Age, London and New York: Routledge, 2006. 
towards more modern forms of social organisation. ${ }^{34}$ If an indigenous community incrementally shifts from tradition to modernity, it may however want to open up only certain aspects of its lifeworld (Husserl), while sticking to traditions with regard to spirituality and religious beliefs. Generally, indigenous groups will not be able and not want to respond to dramatic increases in demand for their products. Small really is beautiful for many indigenous groups. ${ }^{35}$

The differences in the social institutionalisation of creativity (and innovation) in traditional and modern societies have been elaborated elsewhere. ${ }^{36}$ They are responsible for many shortcomings of international law to adequately protect indigenous knowledge assets against misappropriation. Providing remedies against misappropriation or misuse is thus a prerequisite for trade in $\mathrm{ICH}$ being able to support indigenous development. In addition, free prior and informed consent (FPIC) and benefit-sharing must be respected. FPIC is crucial, since indigenous peoples will be willing to produce certain artwork for commercial sale but will want to keep their sacred knowledge secret and to prevent its unauthorised disclosure and subsequent use. ${ }^{37}$ Thus, in accordance with their traditions, they will insist that sacred and secret artefacts must be kept off the art market.

A further complication is legal certainty. From the perspective of the market, a prerequisite for trade in indigenous heritage would certainly be that third-party users know what TCE and TK may or may not be (appropriately) bought or otherwise used. ${ }^{38}$ Accordingly, definitions of TK and TCE and a determination of what subject matter can be traded seem to be necessary for the purpose of legal certainty. The question is who should provide for the required definitions and determinations. Should it be international treaty law? In my view, international law should abstain from providing substantive definitions of, inter alia, TK and TCE (including its tradability) since this would otherwise result in a subjugation of indigenous culture under modern legal concepts. As I have emphasised elsewhere, expressions of indigenous creativity strongly depend on the geographical, spiritual

34 For comprehensive analyses see Miriam Sahlfeld, 'Commercializing Cultural Heritage? Criteria for a Balanced Instrumentalization of Traditional Cultural Expressions for Development in a Globalized Digital Environment', in Christoph B. Graber and Mira Burri-Nenova (eds), Intellectual Property and Traditional Cultural Expressions in a Digital Environment, Cheltenham, UK: Edward Elgar, 2008, pp. 256-286, and, pointing to differences in the reception of modernity between indigenous cultures in Australia and Southeast Asia, Christoph Antons, 'Traditional Cultural Expressions and their Significance for Development in a Digital Environment: Examples from Australia and Southeast Asia', in Christoph B. Graber and Mira Burri-Nenova (eds), Intellectual Property and Traditional Cultural Expressions in a Digital Environment, Cheltenham, UK: Edward Elgar, 2008, pp. 287-301.

35 My thanks to Peter Drahos for this suggestion.

36 For differences in the institutionalisation of creativity see Christoph B. Graber, 'Institutionalization of Creativity in Traditional Societies and in International Trade Law', in Shubha Ghosh and Robin P. Malloy (eds), Creativity, Law and Entrepreneurship, Northampton, MA: Edward Elgar, 2011, pp. 234-263 [hereinafter Graber, 'Institutionalization of Creativity']. For differences in the institutionalisation of innovation, see Gunther Teubner and Andreas Fischer-Lescano, 'Cannibalizing Epistemes: Will Modern Law Protect Traditional Cultural Expressions?', in Christoph B. Graber and Mira Burri-Nenova (eds), Intellectual Property and Traditional Cultural Expressions in a Digital Environment, Cheltenham, UK: Edward Elgar, 2008, pp. 17-45.

37 See Antony Taubman, 'Saving the Village: Conserving Jurisprudential Diversity in the International Protection of Traditional Knowledge', in Keith E. Maskus and Jerome H. Reichman (eds), International Public Goods and Transfer of Technology Under a Globalized Intellectual Property Regime, Cambridge: Cambridge University Press, 2005, pp. 521-564, at p. 534.

38 Susy Frankel, 'Trademarks, Traditional Knowledge and Cultural Intellectual Property', in Graeme B. Dinwoodie and Mark D. Janis (eds), Trademark Law and Theory. A Handbook of Contemporary Research, Cheltenham, UK: Edward Elgar, 2008, pp. 433-463, at p. 448 [hereinafter Frankel, 'TMs, TK and CIP']. 
and social context of their production. ${ }^{39}$ Since "the framework requirements of the respective local culture have to be maintained", ${ }^{40}$ it will be important to capture not only the result, but also the whole process of TK and TCE production. Consequently, international law should provide for procedural solutions rather than substantive ones. That is, rather than itself defining TCE and TK, international law should limit its jurisdiction to stating who is responsible to do this. I will discuss problems posed by such a procedural approach in more detail in the next section.

\section{INTERFACING INDIGENOUS AND MODERN WORLDVIEWS: A PROCEDURAL APPROACH}

As outlined above, the silver bullet to resolving problems of legitimacy in trade and development of ICH seems to be participation of indigenous holders of TK and TCE and a procedural approach to interfacing indigenous and non-indigenous worldviews. However, it needs to be clarified what participation would mean in a context of international trade and what kind of procedures would assure a fair tradeoff between interests of indigenous holders of TK and TCE and interests of nonindigenous customers.

In a first step, I will clarify the concept of a "procedural approach" in general before exploring its concrete meaning in contexts of trade in $\mathrm{ICH}$. The discussions on proceduralist approaches in the field of social theory generally distinguish the concepts of procedural law and procedural justice.

\subsection{PROCEDURALIST THINKING IN SOCIAL THEORY}

The term procedural law is used by law and society theorists to describe a form of legal rationality. ${ }^{41}$ The point is, that procedural law is characterised by a procedural form of rationality as opposed to "substantive" legal rationality. Whereas "substantive" law is concerned with results, procedural law - which is sometimes also referred to as "reflexive law" 42 - is characterised by process-orientation in the design of institutional structures and in organising participation in decisionmaking. ${ }^{43}$

In contrast, the term "procedural justice" is used to value the legitimacy ${ }^{44}$ and/or legitimation ${ }^{45}$ of outcomes that are arrived at through the observance of certain procedures. Procedural justice has been a concern for authors writing in the field of social psychology as well as in philosophy of the law. Within a social psychology context "procedural justice" has been defined by Tom Tyler as the willingness of

39 For Aboriginal culture in Australia the concept of "totemic polygon" has been introduced to describe the complex discursive relationship between the spiritual ancestors, the land, totemic custom and the traditional artist. For more information see Christoph B. Graber, 'Can Modern Law Safeguard Archaic Cultural Expressions? Observations From a Legal Sociology Perspective', in Christoph Antons (ed.), Traditional Knowledge, Traditional Cultural Expressions and Intellectual Property Law in the Asia-Pacific Region, The Hague: Kluwer Law International, 2009, pp. 159-176 [hereinafter Graber, 'Modern Law and CEs'].

40 Teubner and Fischer-Lescano, supra note 36, at p. 41.

41 Gralf-Peter Calliess, Prozedurales Recht, Baden-Baden: Nomos, 1999.

42 Gunther Teubner, 'Substantive and Reflexive Elements in Modern Law' (1983) Law and Society Review, 17, pp. 239-285, at pp. 266-285.

$43 \quad$ Ibid., at p. 257.

44 Legitimacy is the technical term used by social-psychology writers.

45 Legitimation is the technical term used by philosophy of law authors. 
legal subjects "to accept outcomes that are arrived at through procedures that are viewed as being fair". ${ }^{46}$ Whereas this definition is looking at the quality of outputs from an empirical perspective of individual acceptance (legitimacy), legal philosophy (in the tradition of critical theory) is more interested in normative criteria of legitimation. Indeed, Jürgen Habermas and his school would consider legitimate outcomes to be those that have been obtained through procedures respecting a normative standard of institutional structure and participation. ${ }^{47}$ Habermas has championed a proceduralist paradigm of law as the only available model, after both the liberal paradigm and the social-welfare paradigm have lost their persuasive power. ${ }^{48}$ Under the proceduralist paradigm, the law is neither exclusively oriented to securing an equal distribution of rights (the liberal paradigm) nor understood as an instrument for maximising distributive justice (the social-welfare paradigm), but rather conceived as a framework guarantee for process-based rules of fair communication - as detailed in Habermas' theory of deliberative democracy. ${ }^{49}$

Habermas' reference to a proceduralist paradigm of law suggests that there are more commonalities than differences in the discussed approaches to phenomena of procedure, law and justice. The points of convergence of both procedural law and procedural justice writings are that they all refer to a process-based model of regulation (rather than an outcome-based model) and that assuring the participation of stakeholders is considered to be a key requirement. ${ }^{50}$ As a consequence, when speaking of a procedural approach in the remainder of this chapter, I essentially refer to a process-based model of regulation where the participation of the most relevant stakeholders, including indigenous peoples, is a central element.

Social theorist's accentuation of stakeholder participation clearly resonates in more recent UN law and policymaking in the field of indigenous issues. Since the early 1970s, UN institutions have acknowledged "that the greater the participation by indigenous peoples in an institutional process, the more legitimate are the process and its results". ${ }^{51}$ Whereas earlier research feared that an emphasis on procedural solutions and participation mainly served as a "disempowering shift from substantive political goals" 52 (while calling self-determination a substantive goal), the adoption of the UNDRIP made this argument groundless. Indeed, as some authors have argued more recently, the adoption of the UNDRIP has underscored the importance of indigenous participation as an axiom of law and policymaking to be respected not only in relations between states but also at the domestic level. ${ }^{53}$

46 Tom R. Tyler, 'Procedural Justice, Legitimacy, and the Effective Rule of Law' (2003) Crime and Justice, 30, pp. 283-357, at p. 292.

47 At the level of national law such standards will be set by the constitution and will vary according to the nature of the legal or administrative procedure at issue.

48 Jürgen Habermas, Between Facts and Norms. Contributions to a Discourse Theory of Law and Democracy, translation by William Regh, Cambridge, MA: MIT Press, 1996, at pp. 409-410.

49 Ibid., at pp. 418-419; see also Axel Tschentscher, Prozedurale Theorien der Gerechtigkeit. Rationales Entscheiden, Diskursethik und prozedurales Recht, Baden-Baden: Nomos, 2000, at p. 246.

50 There is, however, an important difference in the normative assumptions of the two concepts. Whereas Habermas' concept of "procedural justice" ultimately serves the purpose of "democratisation", the concept of procedural law is not bound by a particular normative a priori. When applied to developing procedures for interfacing indigenous culture and modern law insistence on democratic institutional structures in indigenous communities is often not an option.

51 Chris Tennant, 'Indigenous Peoples, International Institutions, and the International Legal Literature from 1945-1993' (1994) Human Rights Quarterly, 16 (1), pp. 1-57, at p. 49-52.

52 Ibid., at p. 56.

53 Claire Charters, 'A Self-Determination Approach to Justifying Indigenous Peoples' Participation in International Law and Policy Making' (2010) International Journal on Minority and Group Rights, 17, pp. 215240, at pp. 230-232. See also Stephen Allen, 'The UN Declaration on the Rights of Indigenous Peoples and 
To conclude, various strands of social and legal theory view a procedural approach to be more effective than creating substantive rules. ${ }^{54}$ This conclusion extends to resolving problems related to interfacing modern law and local traditions. Indeed, as several socio-psychological studies demonstrate, fair procedures enhance the readiness to accept results, decisions or sentences as being just throughout different groups and cultures. ${ }^{55}$

\subsection{A PROCEDURAL APPROACH TO TRADE IN ICH}

How could a procedural approach be implemented in situations where a decision must be taken about who can legitimately decide whether an asset of indigenous culture can be traded or must be treated as res extra commercium because of its sacred or otherwise important meaning for the community? Here, interests of traditional culture and interests of the global market will often be difficult to reconcile. Whereas an indigenous group as holder of TK or TCE will primarily be interested in free prior and informed consent (FPIC) when deciding about the tradability of a knowledge asset, the primary interest of the market is legal certainty.

In practice, three types of disputes concerning control/ownership over or of a TK or TCE are most likely:

1. dispute between an indigenous community and a non-indigenous third party;

2. dispute between an indigenous community and one of its individual members;

3. dispute between two indigenous communities.

In all three cases the first and central problem requiring clarification is the definition of the indigenous community that can legitimately assert control or property rights in a knowledge asset. There exists no legally binding definition of "indigenous peoples" at the international level. ${ }^{56}$ The most often cited definition stems from José R. Martinez Cobo, as the Special Rapporteur of the Sub-Commission on Prevention of Discrimination and Protection of Minorities, and is contained in addendum 4 of a seminal report that he prepared in 1986-87. ${ }^{57}$ Paragraph 379 provides:

Indigenous communities, peoples and nations are those which, having a historical continuity with pre-invasion and pre-colonial societies that developed on their territories, consider themselves distinct from other sectors of the societies now prevailing in those territories, or parts of them. They form at present non-dominant sectors of society and are determined to preserve, develop and transmit to future

the Limits of the International Legal Project', in Stephen Allen and Alexandra Xanthaki (eds), Reflections on the UN Declaration on the Rights of Indigenous Peoples, 2011, Oxford and Portland Oregon: Hart Publishing, pp. 225-256, at pp. 250-253, discussing indigenous peoples' interests in national and international law from the perspective of Habermas' work on communicative ethics.

54 Similarly, Taubman, supra note 37 , at p. 530, considers establishing alternative dispute resolution mechanisms to be more effective than creating new IP rights to assure effective protection of indigenous cultural knowledge.

55 Günter Bierbrauer and Edgar Klinger, 'Verfahrensgerechtigkeit/Procedural Justice', in Renate Volbert and Max Steller (eds), Handbuch der Rechtspsychologie, Göttingen et al.: Hogrefe, 2008, pp. 507-518; and Tom R. Tyler, Social Justice in a Diverse Society, Oxford: Westview Press, 1997, pp. 75-102.

56 John Scott and Federico Lenzerini, 'International Indigenous and Human Rights Law in the Context of Trade in Indigenous Cultural Heritage', in this volume.

57 UN, José R. Martinez Cobo, 'Study of the Problem of Discrimination Against Indigenous Populations', (UN Doc. E/CN.4/Sub.2/1986/7 and Add. 1-4, 1986). 
generations their ancestral territories, and their ethnic identity, as the basis of their continued existence as peoples, in accordance with their own cultural patterns, social institutions and legal systems.

With regard to historical continuity, paragraph 380 requires an extended period of time reaching into the present of one or more of several factors, including occupation of ancestral lands, common ancestry with the original occupants of these lands, social organisation, language etc.

In line with this definition and with a view to provide practical guidance, EricaIrene Daes, chair of the UN Working Group on Indigenous Populations from 1984 to 2001 and initial drafter of the UNDRIP, suggested that four criteria should be examined in order to establish whether there is an indigenous community or group. These include: 58

1. a community's priority in time with regard to the occupation and use of a territory,

2. aspects of language and social organisation,

3. self-identification as well as self-recognition by other groups, and

4. experience of subjugation, marginalisation, dispossession, exclusion or discrimination, whether or not these conditions persist.

Whereas it will be generally sufficient to rely on the self-identification of a group as indigenous, a clarification would be necessary, if control that a group derives from its indigenous identity is disputed by an indigenous or non-indigenous third-party. If we start with the scenario where the third party involved is non-indigenous, the question needs to be clarified how indigenous laws and customs and modern law should interface. Should this collision of laws be resolved within a framework of indigenous laws and customs or within a framework of modern law?

In Australia, where such questions arise regularly in the realm of Aboriginal land claim cases, it is modern Australian law that formulates the "interface rule". According to Australian case law, an Aboriginal people putting forward a native title claim is required to prove: 59

1. the existence of a distinct community;

2. a traditional connection with or occupation of the land at issue under the laws and customs of the group; and

3. the maintenance of this connection.

Aboriginal claimants bringing a native title case before a court have thus to accept that their claim is squeezed into the doctrinal frame of native title that is provided by Australian common law. For the claimants, the unavoidable consequence of this "choice" of modern law as the framework for resolving such a dispute is losing epistemological sovereignty since indigenous laws and customs are subjugated under the categories imposed by Australian common law. ${ }^{60}$ To illustrate a

58 Erica-Irene Daes (Chairperson-Rapporteur of the Working Group on Indigenous Populations), 'The Concept of “Indigenous Peoples"' (1997) Australian Indigenous Law Reporter, 2(1), pp. 162-174, at p. 173.

59 Lisa Strelein, Compromised Jurisprudence: Native Title Cases Since Mabo, Canberra: Aboriginal Studies Press, 2006, at p. 13.

60 From an Aboriginal perspective, the problem of native title is its logical inconsistency. Although the source of native title is not the common law but the traditional laws and customs, the assumption that sovereignty was acquired by the Crown at the moment of British settlement is not questioned. If constructed consistently, native title would require recognition of "a form of sovereignty" of the colonised people. In reality, however, the law of the traditional inhabitants is subjugated under the law of the colonisers and treated as an element of fact, not law. For a detailed discussion and references see Graber, 'Aboriginal SelfDetermination', supra note 22, at p. 28. For an analysis of similar logical inconsistencies existing in US law, 
consequence of this, it is sufficient to point to difficulties that Aborigines have been facing in the procedure of taking evidence. In earlier years, affidavits of Aboriginal witnesses were excluded by Australian judges as a means to prove links with their land arguably because they are mere "hearsay"; statements of anthropologists, however, were recognised as evidence. ${ }^{61}$ The situation has improved more recently in land rights disputes where Aboriginal evidence is now generally combined with anthropologist's evidence. ${ }^{62}$ Nonetheless, observers have noted "that most of the leading native title and heritage protection judgements devote considerably more space to the evidence of anthropologists, historians and archaeologists than the evidence of Aborigines". 63

In contrast, the Native American Graves Protection and Repatriation Act (NAGPRA) of the United States is an example demonstrating a greater responsiveness of modern law vis-à-vis indigenous custom. The primary purpose of NAGPRA is to resolve conflicts related to the allocation of old or newly excavated human remains, funerary objects, cultural objects etc. of claimed indigenous ownership. ${ }^{64}$ The law of evidence provided by the NAGPRA framework does not require an indigenous community to present sharp-edged proof meeting modern scientific standards, but accepts several soft forms of proof, including stories told by indigenous witnesses to show a cultural affiliation with a claimed object. ${ }^{65}$ Although it is still modern law setting the standard for NAGPRA cases, the subordination of indigenous custom under modern law is cushioned by procedural flexibility towards indigenous social practices.

The second type of disputes, i.e. disputes between an indigenous community and one of its (former) individual members, includes conflicts between traditional rights of the community and individual rights of a group member who does not anymore fully identify with the values of the group. This is a type of conflict that may arise because indigenous culture cannot be immunised against modernisation and it may happen that an individual (indigenous) artist will drift from tribal to modern patterns of artistic expression, due to greater exposure to the global art system. ${ }^{66}$ Such a "modernised" artist may also want to commercialise his or her creations by making use of the protection afforded by modern IP law although he or she may

see Mark Rifkin, 'Indigenizing Agamben: Rethinking Sovereignty in Light of the "Peculiar" Status of Native Peoples' (2009) Cultural Critique, 72, pp. 88-124.

61 For an analysis see Christoph Antons, 'Folklore Protection in Australia: Who is Expert in Aboriginal Tradition?', in Elke Kurz-Milcke and Gerd Gigerenzer (eds), Experts in Science and Society, New York: Kluwer, 2004, pp. 85-103, at pp. 91-98.

62 See Christoph Antons, 'Foster v Mountford: Cultural Confidentiality in a Changing Australia', in Andrew T. Kenyon, Megan Richardson and Sam Ricketson (eds), Landmarks in Australian Intellectual Property Law, New York: Cambride University Press, 2009, pp. 110-125, at p. 121. Neowarra, one of the biggest native title cases of the Australian history, may serve as an illustration. Here, testimonials of Aboriginal witnesses were sometimes used to complement expert opinions provided by anthropologists. See, e.g. Neowarra $v$ Western Australia (2003) FCA 1402, at para. 25 Sundberg J. What is more, with regard to determining the significance of Wanjina and Wungurr for Aboriginal culture, Justice Sundberg made extensive use of Aboriginal expertise (ibid., at paras 164-185). For detailed information on this case see Graber, 'Aboriginal Self-Determination', supra note 22.

63 Gary Edmond, 'Thick Decisions: Expertise, Advocacy and Reasonableness in the Federal Court of Australia' (2004) Oceania, 74, pp. 190-230, at p. 220.

64 On NAGPRA see Goldberg, supra note 25.

65 See Karolina Kuprecht, "The Concept of "Cultural Affiliation" in NAGPRA: Potentials and Limits for International Cultural Property Law', University of Lucerne, Switzerland, i-call Working Paper No. 3 (2011), at pp. 10-13, available online at http://www.unilu.ch/files/icall_working_paper_2011_09_kuprecht_cultural_affiliation_in_nagpra.pdf.

66 For more information see Graber, 'Modern Law and CEs', supra note 39, at pp. 168-169. 
have been "inspired" by traditional cultural knowledge. The indigenous group, however, may claim that the individual artist in producing the artwork was making use of indigenous cultural knowledge that is controlled by the group. ${ }^{67}$

For a conflict rule in this case I suggest relying on the UNDRIP, protecting the right of an indigenous group to live according to its cultural practices, as provided by the right of self-government. With regard to collisions between group rights and rights of individual members of the group, Article 34 UNDRIP states that, as a rule, universally respected individual human rights prevail. Consequently, a weighting of conflicting group rights and individual rights will be necessary on a case-by-case basis and considering the weight of the human rights involved. As a first step in the resolution of such a dispute, I suggest (for the reasons outlined in section 3.3, below) a procedure of national law providing for a presumption that the TK or TCE at issue is controlled by the indigenous group, according to indigenous laws and customs. Indigenous control would imply that the group would have the right to determine who is authorised to "speak" for the group. ${ }^{68}$ Accordingly, an individual person challenging the application of indigenous laws and customs would have to carry the burden of proof to show that modern IP law applies. Rebutting the presumption of indigenous ownership/control will be very difficult since the individual claimant would basically have to demonstrate that the knowledge assets at issue - with the approval of the indigenous community - left the "jurisdiction" of indigenous laws and customs and entered the jurisdiction of modern law. If such a dispute cannot be resolved amicably, then it should be decided by a specialised court, arbitral tribunal or other judicial authority that is in equal parts composed of indigenous and nonindigenous members. ${ }^{69}$

The establishment of institutions capable of assuring legal certainty is a precept for a licit market in TK and TCE to build up. Consequently, rules providing an interface between indigenous custom and modern law will be crucial. This is again a problem to be resolved primarily at the national level and interface rules will depend on the properties of the knowledge asset traded. With regard to specific IP aspects of indigenous knowledge and culture, procedures regulating the interplay between modern law and traditional custom exist in New Zealand. These rules are designed to resolving conflicts of trade mark registration. According to the New Zealand Trade Marks Act, trade marks that are offensive to Māori must not be registered..$^{70} \mathrm{In}$ cases of doubt as to whether a trade mark actually causes offence, the Commissioner of Trade Marks seeks advice from a specially created Māori Advisory Committee. ${ }^{71}$ According to Susy Frankel, "the Commissioner has not differed from the Committee's advice" to date. However, such a difference would be possible if the applicant for the trade mark "submits contrary advice from a different group of Māori". ${ }^{72}$

67 For examples see Peter Shand, 'Scenes from the Colonial Catwalk: Cultural Appropriation, Intellectual Property Rights, and Fashion' (2002) Cultural Analysis, 3, pp. 47-88.

68 Ibid., at p. 64.

69 If the indigenous community wins, then it would be up to it to decide on the basis of its laws and customs whether the TK or TCE can be traded and under what conditions ownership can be transferred to third parties. If the individual claimant wins, then he or she will be free to trade the knowledge asset according to the rules of modern IP and/or property law.

70 See Trade Marks Act 2002 (NZ), s. 17(b)(ii).

71 Section 177 of the Trade Marks Act requires the Commissioner of Trade Marks to appoint an advisory committee to advise the Commissioner whether the registration of a trademark that is, or appears to be, derivative of Māori text and imagery is likely to be offensive to Māori. See http://www.med.govt.nz/templates/Page___1291.aspx.

72 Frankel, 'TMs, TK and CIP', supra note 38, at pp. 450-451. 
With regard to the third type of disputes, i.e. disputes between (two or more) indigenous communities concerning control of indigenous knowledge assets, one could again learn from procedures existing under NAGPRA combining the concept of cultural affiliation with requirements of transparency and notification. The factual context of the NAGPRA procedure of interest is a request by an indigenous group for repatriation of human remains and cultural items that is addressed at a museum currently possessing the claimed objects. The request is likely to be triggered by the museum's notification of an inventory in the US Federal Register ${ }^{73}$ or by a written summary of objects communicated to tribes that could be culturally affiliated. ${ }^{74}$ The purpose of the inventory or summary is to provide information on the Native American human remains and cultural items in the museums possession. Based on consultation with native representatives, cultural affiliation of the claimant will then be evaluated. If the request for repatriation is contested by another indigenous group, claiming to have a better right in the object, then NAGPRA provides that the indigenous groups must resolve the dispute among themselves. ${ }^{75} \mathrm{As}$ long as the conflict is not resolved, the claimed object remains in the custody of the museum. ${ }^{76}$

\subsection{INTERIM CONCLUSIONS}

The examples of native title in Australian case law and NAGPRA in the United States show that it would not make sense to develop a one-size-fits-all solution at the international level to resolving disputes on the allocation of indigenous ownership. Indeed, the UNDRIP recognises in its preamble "that the situation of indigenous peoples varies from region to region and from country to country and that the significance of national and regional particularities and various historical and cultural backgrounds should be taken into consideration". ${ }^{77}$ Accordingly, with regard to dispute settlement, the best way to take account of this plurality of indigenous cultures would probably be procedures to be agreed on at national level possibly in a treaty concluded between the respective indigenous peoples and the state of which they are part - or in an instrument of secondary law. The concept of cultural affiliation, as applied under NAGPRA, shows that it is very well possible to work out procedures showing respect for the particularities of indigenous forms of social organisation and compensating for the difficulties indigenous claimants face when required to prove ownership while still providing for legal certainty. What would be necessary at the level of international law would be some kind of interface rule stating who is responsible to resolve problems related to defining "indigenous peoples", "TK" and "TCE". Moreover, the codification of some guiding principles for the protection of TK and TCE would be necessary at the international level, including mutual recognition of national standards, FPIC, access and benefit-sharing and the

73 This requirement applies to museums and similar agencies that are federally funded; see NAGPRA of 1990, 25 U.S.C. $\S 3003(d)$.

74 NAGPRA of 1990, 25 U.S.C. $§ 3004(a)$.

75 NAGPRA of 1990, 25 U.S.C. $\$ 3001(3)$ (C and D), see Kuprecht, supra note 65, at p. 18.

76 For more detailed information on these NAGPRA procedures see James A. R. Nafziger et al., Cultural Law: International, Comparative, and Indigenous, Cambridge and New York: Cambridge University Press, 2010, at pp. 427-429.

77 UNDRIP, supra note 21, recital 23. 
obligation of states to protect TK and TCE against misappropriation. ${ }^{78}$ These are all issues where human rights concerns overlap with interests of protecting indigenous peoples' knowledge assets. It is thus an open question (going beyond the scope of this chapter) whether these issues should be addressed in a treaty on TK and TCE or, e.g., in a binding international convention on the rights of indigenous peoples.

New Zealand seems to be one of the pioneer users of procedural approaches in areas of trade in traditional knowledge. It is interesting to note, that New Zealand relies on a procedural approach not only when interfacing intellectual property and traditional knowledge protection but also when reserving traditional rights of Māori in its free trade agreements. ${ }^{79}$ The situation in New Zealand is, however, unique because the Treaty of Waitangi, concluded between the Māori and the British Crown in 1840, not only provides the Māori with strong rights in their traditional knowledge and "treasures", 80 but generally permits Māori to negotiate on par with the New Zealand government. To be sure, one should not idealise the situation in New Zealand, as the government is nevertheless a political body, accountable to the general population. Hence, it is liable to oppose Māori interests in seeking to balance Māori demands against the greater good for New Zealand, even if the Māori perceive that the interests are protected by the Treaty.

\section{INDIGENOUS CULTURE AND DEVELOPMENT IN INTERNATIONAL ECONOMIC LAW}

In the previous sections of this chapter, I found that participation of indigenous peoples is the solution to many problems of legitimacy in trade and development of ICH. Based on this insight, I proposed a procedural method to cope with differences between indigenous and modern worldviews that complicate the implementation of rules for legitimate trade in a modern legal context. In the remainder of the chapter I will study the potential of international law and policymaking to better stimulate trade and development in ICH. To this end, I will first briefly assess the current status of indigenous culture and development in international economic law and policymaking. When doing this, activities sponsored by a number of intergovernmental organisations, including the World Trade Organization (WTO), the World Intellectual Property Organization (WIPO), the United Nations Educational, Scientific and Cultural Organisation (UNESCO) ${ }^{81}$ and the Convention

78 See Peter Drahos, 'A Networked Responsive Regulatory Approach to Protecting Traditional Knowledge', in Daniel J. Gervais (ed.), Intellectual Property, Trade and Development. Strategies to Optimize Economic Development in a TRIPS-plus Era, Oxford: Oxford University Press, 2007, pp. 385-415, at pp. 396-401.

79 For more information see Susy Frankel, 'A New Zealand Perspective on the Protection of Mātauranga Māori (Traditional Knowledge)', in this volume.

80 Treaty of Waitangi, Article 2. The Māori version of the Treaty uses the term "taonga", which extends to both the tangible and intangible. See Frankel, ibid., and Jessica C. Lai, 'Māori Culture in the Modern World: Its Creation, Appropriation and Trade', University of Lucerne, Switzerland, i-call Working Paper No. 2 (2010), at pp. 17-19, available online at http://www.unilu.ch/files/icall_working_paper_2011_02_lai_maori_cultural_heritage_undrip.pdf.

81 For the purpose of this chapter, I consider the most relevant activities of UNESCO (particularly those in the field of protecting and promoting the diversity of cultural expressions) as belonging to international economic law. As a justification it is sufficient to refer to UNESCO Convention on Cultural Diversity (CCD) recognising in its Article 1 (g) (and in recital 18 of the Preamble) that cultural products have a dual nature that includes also an economic relevance as goods or services. Indeed, the CCD plays an important role in the regulation of trade and culture at the international, regional and national levels. UNESCO, Convention on the Protection and Promotion of the Diversity of Cultural Expressions, 1440 UNTS 311 
on Biological Diversity (CBD), stand at the foreground. With the exception of UNESCO, most of these activities are IP-centred. In the following section 5, I will then explore an alternative avenue to promote trade and development in $\mathrm{ICH}$ that would go beyond IP-centred approaches.

\subsection{WTO/TRIPS}

In the WTO, development as an end of trade liberalisation is prominently anchored in the Preamble of the Marrakesh Agreement establishing the WTO ${ }^{82}$ and in several declarations emanating from Ministerial conferences. Moreover, discussions on special and differential treatment of developing countries are taking place in the Committee on Trade and Development, one of the WTO's regular bodies where all Members are represented. Since the WTO is a state-centred organisation, these considerations relate to developing countries. Developmental interests of indigenous peoples, however, are not independently mentioned and there is no language in the covered agreements of the WTO directly addressing indigenous issues. ${ }^{83}$ Whereas the interests of certain developing countries may overlap with the interests of their indigenous population to some extent, this has often not been the case for indigenous peoples of industrialised countries such as the United States, Canada, Australia and New Zealand.

While the TRIPs Agreement ${ }^{84}$ of the WTO is without question the most important legal instrument regulating trade in creative expression and innovation, it is a matter of debate whether TK and TCE are covered by its disciplines. ${ }^{85} \mathrm{~A}$ general feeling that numerous modes of TK and TCE remain outside the scope of IP protection led the Doha Ministerial Conference of the WTO in 2001 to explicitly instruct the TRIPS Council, 86 in paragraph 19, to examine, inter alia, "the protection of traditional knowledge and folklore". ${ }^{87}$ In 2005, the Hong Kong Ministerial Conference reaffirmed the mandate for the TRIPS Council in paragraph 44 of its Declaration. ${ }^{88}$ On the one hand, both Ministerial Declarations thereby formalised the TRIPS

(adopted on 20 October 2005, entered into force 18 March 2007). See Christoph B. Graber, 'Trade and Culture', in Rüdiger Wolfrum (ed.), The Max Planck Encyclopedia of Public International Law, Oxford: Oxford University Press, 2010, available online at http://www.mpepil.com/subscriber_article?script=yes\&id=/epil/entries/law-9780199231690-

e1987\&recno=1\&searchType=Quick\&query=Christoph+Beat+Graber [hereinafter Graber, 'Trade and Culture'].

82 WTO, Marrakesh Agreement Establishing the World Trade Organization, 1867 UNTS 154 (adopted on 15 April 1994, entered into force 1 January 1995).

83 See also Macmillan, supra note 14, in this volume.

84 WTO, Agreement on Trade Related Aspects of Intellectual Property Rights, Marrakesh Agreement Establishing the World Trade Organization, Annex 1C, 1869 UNTS 299; 33 ILM 1197 (adopted on 15 April 1994, entered into force 1 January 1995).

85 Graber, 'Institutionalization of Creativity', supra note 36, at pp. 241-242.

86 Council for Trade-Related Aspects of Intellectual Property Rights (TRIPS Council) is one of the three sectoral Councils operating under the General Council. It is the body, open to all Members of the WTO, responsible for the administration of the TRIPS Agreement and in particular for monitoring the operation of the Agreement.

87 WTO, 'Doha Ministerial Declaration', (WTO Doc. WT/MIN(01)/DEC/1, 2001), adopted 14 November 2001 at Doha, Qatar [hereinafter 'Doha Ministerial Declaration'].

88 WTO, 'Hong Kong Ministerial Declaration', (WTO Doc. WT/MIN(05)/DEC, 2005), adopted on 18 December 2005. Paragraph 44 reads as follows: "We take note of the work undertaken by the Council for TRIPS pursuant to paragraph 19 of the Doha Ministerial Declaration and agree that this work shall continue on the basis of paragraph 19 of the Doha Ministerial Declaration and the progress made in the Council for TRIPS to date. The General Council shall report on its work in this regard to our next Session." 
Council's work programme, which had started a few years before the first Declaration in the context of the review of Article 27.3(b) of the TRIPS Agreement. ${ }^{89}$ Article 27.3(b) provides exceptions to the general rule that patents are to be available for any inventions. It relates to the issue of TK in as far as it contains the exception that allows countries to exclude certain types of inventions from patenting, i.e. plants, animals and "essentially" biological processes. On the other hand, the Ministerial Declarations did not limit the examination to the questions relating to TK (and its patentability), but added to the TRIPS Council's mandate the examination of the protection of "folklore", which tends to be examined more through the lens of copyright. Most statements made in the TRIPS Council have related to TK and relatively little has been said with respect to TCE or folklore. ${ }^{90}$

One of the key focuses of the discussion has been the relation of the TRIPS Agreement with the Convention on Biological Diversity (CBD; ${ }^{91}$ see section 4.4, below). ${ }^{92}$ Since 2003, the work on this point has also been undertaken outside the work programme of the TRIPS Council as part of a consultative process carried out by the Director-General of the WTO. His report of 9 June $2008^{93}$ was fed into the July 2008 ministerial meeting, but there was no outcome to this meeting. The fact that TK and TCE became at all an issue of WTO law is mainly a result of developing countries entering the fora where international IPRs are being discussed and negotiated. ${ }^{94}$ According to Gervais, this has also led to a more or less direct representation of indigenous peoples' interests at an international level. ${ }^{95}$ However, this is true only for few countries, including Bolivia ${ }^{96}$ and Venezuela. Beyond that, however, the WTO is not an organisation where indigenous interests are well represented.

\subsection{WIPO}

WIPO's response to the non-existent international protection of indigenous knowledge assets was the establishment of the Intergovernmental Committee on

89 Hannu Wager, 'Biodiversity, Traditional Knowledge and Folklore: Work on Related IP Matters in the WTO' (2008) Intercultural Human Rights Law Review, 3, pp. 215-227, at p. 218.

90 WTO, TRIPS Council Secretariat, 'The Protection of Traditional Knowledge and Folklore: Summary of Issues Raised and Points Made', (WTO Doc. IP/C/W/370/Rev.1, 2006), at p. 2.

91 Rio Convention on Biological Diversity (Rio Convention), 1760 UNTS 79; 31 ILM 818 (opened for signature 5 June 1992, entered into force 29 December 1993).

92 Martin A. Girsberger, 'Legal Protection of Traditional Cultural Expressions: A Policy Perspective', in Christoph B. Graber and Mira Burri-Nenova (eds), Intellectual Property and Traditional Cultural Expressions in a Digital Environment, Cheltenham, UK: Edward Elgar, 2008, pp. 123-149, at p. 134.

93 WTO, General Council Trade Negotiations Committee, Report by the Director-General, 'Issues Related to the Extension of the Protection of Geographical Indications Provided for in Article 23 of the TRIPS Agreement to Products other than Wines and Spirits and those Related to the Relationship Between the TRIPS Agreement and the Convention on Biological Diversity', (WTO Doc. WT/GC/W/591 - TN/C/W/50, 2008).

94 According to Gervais "[ $t$ ]he participation of these countries is essential to ensure that intellectual property norms are understood by all and updated in ways that reflect the concerns of all nations at the tables to negotiate." Daniel J. Gervais, 'The Internationalization of Intellectual Property: New Challenges from the Very Old and the Very New' (2002) Fordham Intellectual Property Media \& Entertainment Law Journal, 12, pp. 929-990, at p. 941.

95 Ibid., at p. 956.

96 Bolivia's representative stated in the TRIPS Council that Bolivia perceives TK and folklore (or TCE) as being part of one single, holistic cultural tradition, and thereby rejects the pure IP perspective realised in the TRIPS Agreement. See, e.g. WTO, 'Minutes of the Meeting on 17 June 2008 of the TRIPS Council', (WTO Doc. IP/C/M/5, 2008). 
Intellectual Property and Genetic Resources, Traditional Knowledge and Folklore (IGC) in 2001. Although the discussions in the WIPO IGC on sui generis instruments to protect TK, TCE and genetic resources have been on-going for more than ten years, relatively little progress has been made. After 19 sessions, the IGC has reached the stage of text-based negotiations, but no agreement is in view even with regard to the key objectives and principles of the new TCE and TK instruments and views diverge between indigenous and non-indigenous stakeholders and often even between indigenous communities. ${ }^{97}$ For indigenous peoples, one central question is whether the new instruments should also extend to TCE and TK of a non-indigenous origin.

The idea of "development" is strongly present in the texts drafted by the IGC. 98 With the launch of its Development Agenda 2007, WIPO generally started to look at IP from a development perspective. ${ }^{99}$ The purpose of this broader view is to confront the vast social effects of IP law beyond creating incentives for innovation and maximising revenues. The scope of the WIPO Development Agenda includes knowledge assets of indigenous peoples in developing and developed countries.

\subsection{UNESCO}

Strengthening the contribution of culture to sustainable development has been a goal of UNESCO policymaking since the launch of the World Decade for Cultural Development (1988-1998). With regard to its activities with indigenous peoples, UNESCO stresses that it is "framed by its missions to protect and promote cultural diversity, encourage intercultural dialogue and enhance linkages between culture and development". ${ }^{100}$ Notwithstanding these euphonious promises, UNESCO's most relevant standard-setting instrument in this context, the Convention on Cultural Diversity (CCD), ${ }^{101}$ does not respond sufficiently to the interests of indigenous peoples. ${ }^{102}$ The failure to properly protect cultural interests of indigenous peoples can

97 For more information see Christoph Antons, 'Intellectual Property Rights in Indigenous Cultural Heritage: Basic Concepts and Continuing Controversies', in this volume; and Girsberger and Müller, supra note 3.

98 In the Draft on TCE, to this end two objectives are relevant: objective (iii), which aims to "contribute to the welfare and sustainable economic, cultural, environmental and social development of such peoples and communities"; and objective (xii), which aims to promote the development of indigenous peoples and communities and "legitimate trading activities". Objective (xii) promotes the use of TCE for the development of indigenous peoples and communities, where desired by them. Moreover, the objective recognises the TCE as "an asset of the communities that identify with them, such as through the development and expansion of marketing opportunities for tradition-based creations and innovations". WIPO, IGC, Secretariat, 'The Protection of Traditional Cultural Expressions', Nineteenth Session (WIPO Doc. WIPO/GRTKF/IC/19/4, 2011).

99 The WIPO Development Agenda was established by the WIPO General Assembly in October 2007. It includes a set of 45 recommendations designed to enhance the development dimension of the organisation's activities. Recommendation 18 (related to norm-setting, flexibilities, public policy and public domain) urges the IGC "to accelerate the process on the protection of genetic resources, traditional knowledge and folklore, without prejudice to any outcome, including the possible development of an international instrument or instruments." In addition to the adoption of the Development Agenda, WIPO Member States also approved a recommendation to establish a Committee on Development and Intellectual Property. See generally the chapters in Neil W. Netanel (ed.), The Development Agenda. Global Intellectual Property and Developing Countries, New York: Oxford University Press, 2009.

100 See http://www.unesco.org/en/cultural-diversity/action-in-favour-of-cultural-diversity/unesco-andindigenous-peoples-partnership-for-cultural-diversity/ .

101 Supra note 81.

102 For a comprehensive assessment of further UNESCO instruments relevant for ICH, including the 1972 World Cultural Heritage Convention and the 2003 Convention for the Safeguarding of Intangible Cultural Heritage, see the chapter of Coombe and Turcotte, supra note 3. See also Francesco Bandarin, 
be explained by the drafting history of the CCD. The convention was designed by its drafters to protect national entertainment industries rather than creative expressions of indigenous peoples. ${ }^{103}$ Indeed, a reference to TCE and indigenous peoples was introduced only at a late stage of the negotiations. ${ }^{104}$ Although the adopted text does mention TCE and indigenous peoples a few times, ${ }^{105}$ the relevant provisions do not address the rights of the indigenous peoples themselves but those of the states whose territory is affected. ${ }^{106}$ Similarly, the 2003 UNESCO Convention for the Safeguarding of Intangible Cultural Heritage ${ }^{107}$ is not considered by indigenous peoples to adequately furthering their interests. ${ }^{108}$

\subsection{CBD}

Over the last decades, the Convention on Biological Diversity (CBD) ${ }^{109}$ has gained prominence as forum for discussing issues of traditional knowledge. Although the CBD focuses on TK that is associated with genetic resources, discussions on disclosure or certification of origin held therein may also be relevant for other forms of TK relating to the subject matter of intellectual property applications. With regard to access to and benefit-sharing of knowledge that is held by indigenous peoples, the adoption of the Nagoya Protocol by the CBD Conference of Parties in October 2010 is most important. ${ }^{110}$ Its Article 7 requires parties to ensure that traditional knowledge associated with genetic resources that is held by indigenous and local communities is accessed with the free prior and informed consent (FPIC) of these communities, and that mutually agreed terms have been established. ${ }^{111}$ It thus satisfies requirements of indigenous participation in any legal

'International Trade in Indigenous Cultural Heritage: Comments from UNESCO in Light of its International Standard-Setting Instruments in the Field of Culture', in this volume.

103 See Federico Lenzerini, 'Indigenous Peoples' Cultural Rights and the Controversy Over Commercial Use of their Traditional Knowledge', in Francesco Francioni and Martin Scheinin (eds), Cultural Human Rights, Leiden et al.: Martinus Nijhoff Publishers, 2008, pp. 119-149, at p. 130.

104 See Christoph B. Graber, 'Traditional Cultural Expressions in a Matrix of Copyright, Cultural Diversity and Human Rights', in Fiona Macmillan (ed.), New Directions in Copyright Law, vol. V, Cheltenham: Edward Elgar, 2007, pp. 45-71, at pp. 54-55.

105 Paragraph 8 of the preamble recognises, "the importance of traditional knowledge". Furthermore, paragraph 13 of the preamble recognizes that diversity of cultural expressions, including "traditional cultural expressions", is an important factor that allows peoples and individuals to express and to share with others their ideas and values. Finally, paragraph 15 of the preamble, Article 2 (principle 3) and Article 7.1(a) refer to the relevance of the CCD for persons belonging to indigenous peoples.

106 Graber, 'Trade and Culture', supra note 81, at para. 22; Mira Burri-Nenova et al., 'The Protection and Promotion of Cultural Diversity in a Digital Networked Environment: Mapping Possible Advances to Coherence', in Thomas Cottier and Panagiotis Delimatsis (eds), The Prospects of International Trade Regulation: From Fragmentation to Coherence, Cambridge and New York: Cambridge University Press, 2011, pp. 359-393, at pp. 368-369.

107 UNESCO, Convention for the Safeguarding of the Intangible Cultural Heritage, 2368 UNTS 1 (adopted on 17 October 2003, entered into force 20 April 2006)

108 As Coombe and Turcotte, supra note 3, highlight, indigenous peoples were not involved in the drafting of the UNESCO Convention for the Safeguarding of Intangible Cultural Heritage. This explains many of the identified shortcomings of this instrument and questions its legitimacy to further the interests of indigenous peoples. See also Bandarin, supra note 102.

109 Supra note 91.

110 Nagoya Protocol on Access to Genetic Resources and the Fair and Equitable Sharing of Benefits Arising from their Utilization to the Convention on Biological Diversity (UN Doc. UNEP/CBD/COP/DEC/X/1) (adopted on 19 October 2010). For a more comprehensive assessment of the Nagoya Protocol and its relationship with the CBD see Scott and Lenzerini, supra note 56 .

111 The Nagoya Protocol is open for signatures until 1 February 2012. 
or political process involving their traditional knowledge, as outlined above (sections 2 and 3.2). Furthermore, Article 5 of the Protocol provides for the need to ensure that benefits arising from the use of traditional knowledge associated with genetic resources are shared in a fair and equitable way with indigenous peoples, in accordance with domestic regulation. Reflecting the institutionalisation of access and benefit-sharing rights of indigenous peoples in Articles 7 and 5, Scott and Lenzerini predict in their contribution to this volume that the Nagoya Protocol will potentially play an important role in future discussions on the regulation of trade in ICH. ${ }^{112}$

\subsection{SUMMARY}

To summarise, it appears that the interrelationship between cultural knowledge, trade and development has entered the thinking of the most important fora of international economic law. The above assessment of activities in WTO/TRIPS, WIPO, UNESCO and CBD is confirmed in the broader context of the UN in general by the 2008 UN Creative Economy Report. ${ }^{113}$ This report was drafted by the United Nations Conference on Trade and Development (UNCTAD) and the United Nations Development Programme (UNDP) in cooperation with UNESCO, WIPO and the International Trade Centre (ITC). It emphasised the link between the economy and culture as a "new development paradigm" and chapter 6.4 explicitly deals with TCE. The new trend goes hand in hand with dynamics in the UN General Assembly, which, on 19 December 2010, adopted a resolution on culture and development as a follow-up to the 2010 UN Millennium Summit. ${ }^{114}$ This resolution emphasises the important contribution of culture for sustainable development and for the achievement of national and international development objectives, including the Millennium Development Goals. ${ }^{115}$ This resolution is of particular relevance, since the eight Millennium Development Goals do not mention culture explicitly.

To be sure, these noble words remain merely programmatic and not much has been undertaken to effectively improve the status of indigenous peoples and independently address their interests in the realm of culture, trade and development. Often, indigenous interests and interests of developing countries have been mentioned in the same breath. However, as recent discussions show, indigenous peoples have interests that are distinct from interests of developing countries. ${ }^{116}$ International law, which is generally state-centred, does not seem to be prepared to recognise indigenous peoples' international juridical personality beyond declaratory texts. Although some international fora have intensified their efforts to facilitate

112 Scott and Lenzerini, supra note 56.

113 According to the United Nations Creative Economy Report 2008 "a new development paradigm is emerging that links the economy and culture, embracing economic, cultural, technological and social aspects of development at both the macro and micro levels. Central to the new paradigm is the fact that creativity, knowledge and access to information are increasingly recognized as powerful engines driving economic growth and promoting development in a globalizing world." UN, UNCTAD, United Nations Creative Economy Report 2008, 'The Challenge of Assessing the Creative Economy: Towards Informed Policy-making', (UN Doc. UNCTAD/DITC/2008/2, 2008), at p. 3.

114 See UNESCO, Executive Office, Sector for Culture, 'The United Nations Recognizes the Role of Culture for Development' (23 December 2010), available at http://portal.unesco.org/culture/en/ev.phpURL_ID=41466\&URL_DO=DO_TOPIC\&URL_SECTION=201.html (11.7.2011).

115 See UN, United Nations Development Programme, 'What are the Millennium Development Goals?', available at http://www.undp.org/mdg/basics.shtml.

116 For examples see, e.g. Drahos, supra note 78, at p. 394. 
indigenous participation, ${ }^{117}$ the holders of TK and TCE face insurmountable obstacles in finding the necessary means and capacity to effectively playing a part in the relevant discussions and negotiations. ${ }^{118}$ It also seems doubtful whether any of the mentioned instruments under negotiation, could - if eventually entered in force - be successfully implemented in states where indigenous rights of self-government in cultural matters are not recognised. What is more, the on-going discussions on creating new WIPO instruments on TCE and TK are not sufficiently coordinated with concurring debates in the TRIPS council and/or in the CBD. The relevant activities of these fora as well as of UNESCO are determined by the respective organisation's specialisation and there is a risk that eventual outcomes will increase rather than reduce the existing fragmentation of the relevant law on $\mathrm{ICH}$. These difficulties have provoked critical comments generally questioning the viability of top-down solutions to the problem. ${ }^{119}$

\section{Pros and Cons of Preferential Trade Rules for Indigenous PeOPles Stimulating a More ACTIVE ROLE OF INDIGENOUS PEOPLES IN GLOBAL TRADE}

The analysis in the above section revealed that international economic law in its current shape does not sufficiently respond to indigenous interests in the trade and development of their cultural heritage. Whereas intellectual property aspects of international economic law were at the foreground so far, I would now like to discuss the viability of an alternative option. The question to be studied is whether preferential trade rules for indigenous cultural goods and services would be a means to stimulating a more active role of indigenous peoples in global trade. Whereas preferential treatment in trade relations is already an important issue of international trade regulation, it has hardly been discussed whether such rules could also be drafted for indigenous peoples. The basis for the following appreciation is an earlier paper published elsewhere, ${ }^{120}$ where I suggested studying the possibility of creating preferential rules for goods and services of indigenous origin in a WTO context and outlined a possible pathway to this end. The document was discussed as a reference paper in the expert workshop ${ }^{121}$ from which this book results. The following is a restatement of the original ideas and reflects what I learned from the many interesting comments that were expressed by a number of colleagues at that occasion.

As outlined, the WTO views the promotion of economic development being one of the primary aims of international trade ${ }^{122}$ and the preamble of the WTO

In 2004, the Conference of Parties of the CBD established a Voluntary Trust Fund to facilitate the participation of indigenous and local communities in the work of the convention. See UN and UNEP, 'Voluntary Fund', available at http://www.cbd.int/traditional/fund.shtml. Similarly, WIPO Members set up a Voluntary Fund in 2005 to facilitate the participation of accredited indigenous and Local Communities in the sessions of the IGC. See WIPO, 'Voluntary Fund', available at http://www.wipo.int/tk/en/ngoparticipation/voluntary_fund/.

118 See Kathy Bowrey, 'International Trade in Indigenous Culture Heritage: Legal and Policy Issues. An Australian Perspective', in this volume; Martin Girsberger and Benny Müller, supra note 3; and Drahos, supra note 78 , at p. 400 .

119 See Drahos, supra note 78, at pp. 414-415.

120 Graber, 'Institutionalization of Creativity', supra note 36

121 The exploratory workshop on 'International Trade in Indigenous Cultural Heritage' took place in Lucerne from 17-19 January 2011. It was organised by i-call, the research centre for international communications and art law, at the school of law of the University of Lucerne.

122 See WTO, Doha Ministerial Declaration, supra note 87, particularly at para. 2. 
Agreement recognises the "need for positive efforts designed to ensure that developing countries ... secure a share in the growth of international trade commensurate with the needs of their economic development" ${ }^{\prime 23}$ In this spirit, the WTO legal framework contains a number of rules providing for special and differential (S\&D) treatment for developing countries, including for example, longer transitional time periods, special rules on dispute settlement, flexibility of commitments or technical assistance. ${ }^{124}$ Moreover, the WTO provides for a General System of Preferences (GSP) exception. As GSPs are used by WTO developedcountry Members to increase the share of developing-country Members in international trade, an exception from the most-favoured-nation (MFN) obligation of Article 1 GATT ${ }^{125}$ is indeed necessary to avoid an inconsistency with existing multilateral obligations.

As Gregory Shaffer and Yvonne Apea have emphasised, it is necessary to understand the raison d'etre and the functioning of GSPs within a historical context of colonialism. In 1947, when the GATT was signed, many signatories of the agreement still had colonies. ${ }^{126}$ To make sure that the trade preferences granted by the colonising GATT members to their colonies would not become GATT inconsistent, Article I:2 GATT provided for so-called "colonial" or "imperial" preferences. In the period of decolonisation, the former colonies sought to join forces in a group of developing countries and in 1964 UNCTAD was established as a "counterpart to GATT that would focus on development priorities." ${ }^{127}$ At UNCTAD I in 1964, a report was adopted to promote the idea of trade preferences for developing countries in the form of lower tariffs. ${ }^{128}$ Since this was inconsistent with the MFN disciplines of the GATT, a waiver for a Generalised System of Preferences favouring trade of less developed countries was granted in 1971 for a ten year period. ${ }^{129}$ Shortly before the GSP waiver expired, GATT Members took a decision in 1979 to permanently authorise the GSP programmes. ${ }^{130}$ This decision that became known as the "Enabling Clause" was incorporated into GATT 1994. ${ }^{131}$

As John Jackson pointed out, there was no legal obligation for developed countries to grant GSP programmes and "no particularly detailed requirements as to

123 See Marrakesh Agreement establishing the World Trade Organization, supra note 82, Preamble, recital 2.

124 For an overview see Peter Van den Bossche, The Law and Policy of the World Trade Organization, 2nd edn, Cambridge: Cambridge University Press, 2008, at p. 723-724.

125 WTO, General Agreement on Tariffs and Trade, Marrakesh Agreement Establishing the World Trade Organization, Annex 1A, 1867 UNTS 187; 33 ILM 1153 (adopted on 15 April 1994, entered into force 1 January 1995).

126 Gregory Shaffer and Yvonne Apea, 'GSP Programmes and Their Historical-Political-Institutional Context: Comment on Lorand Bartels', in Thomas Cottier et al. (eds), Human Rights and International Trade, Oxford and New York: Oxford University Press, 2005, pp. 488-503, at p. 492.

127 Ibid., at p. 493.

128 John H. Jackson, The World Trading System: Law and Policy of International Economic Relations, 2nd edn, Cambridge, MA: MIT Press, 1997, at p. 322.

129 GATT Secretariat, Waiver, 'The Generalized System of Preferences', (GATT Document BISD 18S/24, 25 June 1971).

130 GATT, 'Differential and More Favourable Treatment, Reciprocity and Fuller Participation of Developing Countries', (GATT Doc. L/4903, 1979). Lorand Bartels, 'Conditionality in GSP Programmes: The Appellate Body Report in European Communities - Conditions for the Granting of Tariff Preferences to Developing Countries and its Implications for Conditionality in GSP Programmes', in Thomas Cottier et al. (eds), Human Rights and International Trade, International Economic Law Series, Oxford and New York: Oxford University Press, 2005, pp. 463-487, at p. 464.

131 For more information see Bernard Hoekman, 'More Favorable Treatment of Developing Countries: Ways Forward', in Richard Newfarmer (ed.), Trade, Doha, and Development: Window Into the Issues, Washington, DC: World Bank, 2006, pp. 213-221; Seung W. Chang, 'WTO for Trade and Development Post-Doha' (2007) Journal of International Economic Law, 10 (3), pp. 553-570; Van den Bossche, supra note 124, at pp. 728-731. 
what should be the shape and framework of GSP". ${ }^{132}$ As a consequence, GSP programmes were implemented by major industrialised countries at different times and with varying features. ${ }^{133}$ Considering the rather fuzzy normative contour and multiple functionality of GSP programmes, it seems tempting to explore whether such programmes could extend to trade preferences for cultural goods (or services) of indigenous origin. ${ }^{134}$

To foreclose the results of my exploration that - as mentioned above - was guided by many insightful comments of a number of colleagues, such an endeavour would be burdened by several flaws. The first flaw is related to the conditionality of GSP programmes in general. "GSP conditionality" is a shortcut formula used to describe that GSP programmes, as a rule, provide trade preferences to developing countries under certain conditions only. The EU and the US - being the major WTO Members to run a GSP programme - provide for numerous conditions to the granting of tariff preferences. ${ }^{135}$ The open-ended scope of GSP conditionality in the EU's programme was exposed in European Communities - Tariff Preferences. ${ }^{136}$ The EU GSP under scrutiny in that case provided for additional preferences that were granted to countries participating in a programme to combat drug production and trafficking. The standard of drug combat measures was apparently applied very broadly, since the European Commission found that Pakistan would meet the requirements of the scheme because of the countries" "changed position on the Taliban regime and its determination to return to democratic rule". ${ }^{137}$ Whereas the EU GSP provides conditions that a developing country must meet in order to be granted the additional preferences, the US follows a "negative" approach to GSP conditionality. ${ }^{138}$ There is a great variety of criteria that would reduce the chances of a developing country to benefit from the US GSP including, for example, communism, violation of workers' rights or child labour, or even insufficient standards of IP protection. ${ }^{139}$

Judgements in the academic literature regarding the pros and cons of GSP conditionality are divided. Whereas some scholars acknowledge the potential of carefully drafted conditions "to advance the cause of human rights", ${ }^{140}$ or to promote social goals, ${ }^{141}$ others point to neo-colonial strands in their texture and to playing on asymmetric power relations in international trade. Philip Alston criticised the fuzzy scope of GSP programmes, offering the US and the EC a carte blanche to opt for

132 Jackson, supra note 128 , at p. 323.

133 According to UNCTAD, the following countries are currently providing GSP programmes: Australia, Belarus, Canada, the European Union, Japan, New Zealand, Norway, the Russian Federation, Switzerland, Turkey and the United States. See UNCTAD, 'Generalized System of Preferences', available at http://www.unctad.org/Templates/Page.asp?intItemID=1418\&lang=1.

134 See Graber, 'Institutionalization of Creativity', supra note 36, at pp. 246-248, where I have indeed suggested to explore GSP conditionality as a means to promote indigenous peoples' participation in trade with cultural heritage assets.

13519 U.S.C. 2462. See Barnali Choudhury et al., 'A Call for a WTO Ministerial Decision on Trade and Human Rights', in Thomas Cottier and Panagiotis Delimatsis (eds), The Prospects of International Trade Regulation: From Fragmentation to Coherence, Cambridge and New York: Cambridge University Press, 2011, pp. 323-358 at 337-338.

136 WTO, Appellate Body Report, European Communities - Conditions for the Granting of Tariff Preferences to Developing Countries, WT/DS246/AB/R, adopted 20 April 2004.

137 EU Commission, 'Briefing on 12 March 2002', as quoted by Bartels, supra note 130, at p. 467.

138 Shaffer and Apea, supra note 126, at p. 494.

139 On the US GSP see Bartels, supra note 130, at p. 467; Choudhury et al., supra note 135, at p. 337.

140 Choudhury et al., supra note 135, at p. 336.

141 For a discussion see Krista Nadakavukaren Schefer, Social Regulation in the WTO: Trade Policy and International Legal Development, Cheltenham, UK: Edward Elgar, 2010, at pp. 246-259. 
"whatever standards they chose in a given situation". ${ }^{142}$ Peter Drahos and John Braithwaite denounced the US as having used GSP conditionality in a carrot and stick manner since the first amendment of the GSP in 1984 for the purpose of implementing higher standards of IP protection in beneficiary countries. ${ }^{143}$ Shaffer and Apea similarly found fault with the United States' use of GSP conditionality "as 'a key lever' to press recalcitrant developing countries to agree to the inclusion of the TRIPS Agreement into the new WTO system in 1995". ${ }^{144}$

The second and main flaw is the state-centrism of GSP programmes. Since indigenous peoples are not recognised as legal subjects of international law, it would be difficult to "target" the benefits of a GSP programme at indigenous peoples. Accordingly, partners of a GSP programme would not be indigenous peoples themselves but the governments of the territories where they live. This would be problematic since the interests of indigenous peoples are often not identical (if not in conflict) with the interests of the country where they live. ${ }^{145}$ Would it be possible to absorb this deficiency by requiring the beneficiary country to assure participation of indigenous peoples in the drafting and administration of the GSP programme? One could think of referring to the UNDRIP and obliging a beneficiary country to endorse the Declaration and respect inter alia the therein provided standards of indigenous self-determination and self-government or FPIC in issues related to their cultural heritage. ${ }^{146}$ Such an approach does not seem excluded outright since the EU GSP provides for many references to human rights instruments. ${ }^{147}$ According to the current EU GSP, a special incentive arrangement for sustainable development and good governance may be granted to a beneficiary country that has ratified and effectively implemented inter alia 16 human rights conventions. ${ }^{148}$ In addition, the beneficiary country is obliged to accept a regulatory monitoring of the instruments' implementation as provided by the various conventions. ${ }^{149}$

However, in the constellation of our research involving indigenous peoples of the USA, Canada, Australia and New Zealand, this would not seem realistic. Since GSP programmes are not meant to offer preferential treatment to rich countries, it is indeed difficult to imagine a country willing to extend its GSP to the United States, for example.

To summarise, GSP programmes come at a high cost for the multilateral trading system. Although some commentators prize GSP as a means to further human rights, sceptical views prevail, criticising their fuzzy scope, and, because the allocation of benefits is frequently changed, risks of arbitrary application and a lack of legal certainty. ${ }^{150}$ Even more important in our context is that GSP programmes are of limited benefit for indigenous peoples since preferential treatment is always granted to countries and not to groups within a country. In context, a similar objection must be raised against trade preferences for cultural reasons as provided by the UNESCO

142 Philip Alston as quoted in Shaffer and Apea, supra note 126, at p. 497

143 Peter Drahos and John Braithwaite, Information Feudalism: Who Owns the Knowledge Economy?, New York: New Press, 2003, at pp. 86-90 and 196-197.

144 Shaffer and Apea, supra note 126, at p. 498.

145 According to sources quoted in Drahos, supra note 78, at p. 393, indigenous peoples are the victims rather than the partners of national governments in many parts of the world.

146 FPIC is a requirement provided in Articles 10, 11, 19, 28, 29 and 32 of UNDRIP.

147 Council Regulation (EC) No. 732/2008 of 22 July 2008 (2008) Official Journal of the European Union, L 211/1, applying a scheme of generalised tariff preferences for the period from 1 January 2009 to 31 December 2011. See Choudhury et al., supra note 135, at p. 338.

148 Ibid., Article 8(1)(a).

149 Ibid., Article 8(1)(b).

150 Shaffer and Apea, supra note 126, at p. 498. 
CCD. Article 16 CCD provides that developed countries shall accord "preferential treatment to artists and other cultural professions and practitioners, as well as cultural goods and services from developing countries". In contrast to most other provisions of the Convention, which are of a non-binding nature, Article 16 is a clearcut obligation. ${ }^{151}$ However, Article 16 CCD does not recognise the specific interests of indigenous peoples in developing as well as developed countries. ${ }^{152}$ This is due to the centrality of state sovereignty, which is a guiding principle underpinning the CCD. ${ }^{153}$ As a consequence, all rights and obligations stemming from the CCD are attributed to states. The UNESCO example confirms that the non-existence of indigenous peoples as subjects of international law is one of the major obstacles to any adequate protection of ICH at the international level.

\section{CONCLUSION}

This chapter starts from the insight that a non-indigenous mind cannot access the worldviews of indigenous peoples. The (non-indigenous) legal scholar's response to this epistemological relativism is to apply a procedural methodology in law and policymaking on $\mathrm{ICH}$ trade and development (participation of $\mathrm{ICH}$ holders) as well as in the process wherein these issues are scientifically reflected (participation of indigenous scholars). Opting for process-based solutions and participation would suggest preferring decentralised structures of decision-making to centralised ones. Similarly, the principle of subsidiarity requires that political matters should be handled at the lowest or least centralised level where an effective fulfilment of the task at issue is still possible. ${ }^{154}$ Applying the principle of subsidiarity to deciding on the appropriate level of regulation in ICH trade and development would imply that definitions of "indigenous peoples", "TK" and "TCE", should be made at the national level - considering the above highlighted plurality of indigenous cultures around the world. Rules of international law, however, would be needed to guarantee a framework of minimal standards or to provide interface and coordination rules. With regard to minimal standards, international law should provide for obligations for states to respect a number of key principles, including

151 See Christoph B. Graber, 'Substantive Rights and Obligations Under the UNESCO Convention on Cultural Diversity', in Hildegard Schneider and Peter Van den Bossche (eds), Protection of Cultural Diversity from a European and International Perspective, Antwerpen and Portland, Oregon: Intersentia, 2008, pp. 141-162, at p. 151.

152 It is noteworthy that in the ongoing discussions at UNESCO on the implementation of Article 16 CCD, Switzerland - in its response to a questionnaire distributed by the Intergovernmental Committee (established under the CCD) - suggested that signatories should seek internally, that indigenous peoples benefit from preferential treatment in the trade of TK and TCE. See Swiss Confederation, 'Convention sur la protection et la promotion de la diversité des expressions culturelles, réponse de la Suisse au questionnaire sur l'art 16 - Traitement preferentiel' (2009), available online at http://www.unesco.org/culture/culturaldiversity/Suisse, at pp. 3-5.

153 Rachel Craufurd Smith, 'The UNESCO Convention on the Protection and Promotion of Cultural Expressions: Building a New World Information and Communication Order?' (2007) International Journal of Communication, 1, pp. 24-55, at p. 37. The sovereignty of the State Parties in the cultural field is included in Article 2(2) as one of the eight guiding principles underpinning the Convention.

154 Subsidiarity is an organising principle that is well established in a number of federal constitutions around the world, in the European Union and in international law. For an overview and further references see Isabel Feichtner, 'Subsidiarity', in Rüdiger Wolfrum (ed.), The Max Planck Encyclopedia of Public International Law, Oxford: Oxford University Press, 2007, available online at http://www.mpepil.com/subscriber_article?script=yes\&id=/epil/entries/law-9780199231690e1477\&recno=3\&searchType=Quick\&query=Isabel+Feichtner. 
indigenous self-government, collective rights attribution, FPIC and access and benefit-sharing etc. With regard to coordination, commentators have convincingly argued for the principle of mutual recognition of national standards in preference to a national treatment requirement. ${ }^{155} \mathrm{~A}$ question for further research would be whether minimal standards and interface rules should be established in the planned WIPO treaties on TK, TCE and genetic resources (GR) or rather in a future binding international instrument on indigenous rights.

As the second part of the chapter revealed, international law's potential for stimulating ICH trade and development is rather limited. Although the relevant fora of international economic law as well as the $\mathrm{UN}$ are aware of the linkage between $\mathrm{ICH}$ trade and development, so far few concrete effects have resulted from a remarkable production of soft and hard norms on TCE, TK and GR. I also had to learn that my original idea of using preferential trade rules as an instrument to further ICH trade and development does not withstand further examination. Besides much collateral damage to the multilateral trading order such a scheme would not be in the interest of indigenous peoples, mostly because of international law's statecentralism. Considering the many obstacles top-down solutions of international law are faced with, it makes sense to study bottom-up alternatives more closely, including the use of private certification standards to advance ICH trade and development. ${ }^{156}$ As the reader of this volume will note, several contributors have referred to such new approaches ${ }^{157}$ and the final chapter enters into this discussion in more depth. ${ }^{158}$ Exploring international law's potential to empower indigenous peoples developing autonomous local projects of $\mathrm{ICH}$ commercialisation would be an important contribution to further indigenous self-determination and selfgovernment in contexts of culture, trade and development.

See Susy Frankel, 'Attempts to Protect Indigenous Culture through Free Trade Agreements', in this volume; and Drahos, supra note 78, at p. 401.

156 Christoph B. Graber and Jessica C. Lai, 'Indigenous Cultural Heritage and Fair Trade - Voluntary Certification Standards in the Light of WIPO and WTO Law and Policymaking' (2011) Prometheus, 29, pp. 287-308.

157 See for example Coombe and Turcotte, supra note 3 .

158 See Christoph B. Graber, Karolina Kuprecht and Jessica C. Lai, ‘The Trade and Development of Indigenous Cultural Heritage: Completing the Picture and a Possible Way Forward', in this volume. 